\title{
DETERMINAN MIGRASI BERULANG MANTAN PEKERJA MIGRAN INDONESIA
}

\author{
Studi Kasus di Desa Purworejo, Kabupaten Kendal
}

\author{
Repeated Migration Determinants of Former Indonesian Migrant Worker: \\ A Case Study in Purworejo Village, Kendal Regency
}

\author{
Farakh Khoirotun Nasida ${ }^{1}$, Suryanto Aloysius ${ }^{2}$ \\ Politeknik Statistika STIS ${ }^{1}$ \\ Politeknik Statistika STIS 2 \\ Jalan Otto Iskandardinata Raya No. 64C Jakarta Timur \\ E-mail: 16.9121@stis.ac.id
}

\begin{abstract}
ABSTRAK
Migrasi tenaga kerja internasional berkembang pesat seiring dengan transformasi demografi, menimbulkan berbagai pola perpindahan baru, salah satunya migrasi berulang. Sebagai negara pengirim tenaga kerja internasional, Indonesia dihadapkan pada problematika kompleks terkait perlindungan dan dampak migrasi berulang terhadap kehidupan sosial Pekerja Migran Indonesia (PMI). Dengan mengambil studi kasus di Desa Purworejo, Kabupaten Kendal, penelitian ini bertujuan untuk mengetahui gambaran umum, variabel yang memengaruhi, dan kecenderungan migrasi berulang mantan PMI dari karakteristik ekonomi, modal manusia, demografi, dan modal sosialnya. Penelitian ini menggunakan sumber data primer dengan metode pengambilan sampel stratified systematic. Dari analisis deskriptif, didapatkan bahwa mayoritas PMI di Desa Purworejo melakukan migrasi berulang. Melalui persamaan regresi logistik biner yang terbentuk, varaibel sektor pekerjaan, pendidikan, pelatihan kewirausahaan, umur pertama migrasi, dan status perkawinan terbukti secara signifikan memengaruhi migrasi berulang. Mantan PMI yang pada migrasi pertamanya bekerja pada sektor informal, berpendidikan SMP ke bawah, tidak pernah mengikuti pelatihan kewirausahaan, berumur muda, dan belum menikah memiliki kecenderungan lebih tinggi untuk melakukan migrasi berulang. Sedangkan variabel pengalaman kerja, penguasaan bahasa, jumlah ART, keikutsertaan komunitas migran, dan keberadaan keluarga migran tidak berpengaruh signifikan. Pemerintah diharapkan dapat meningkatkan kerja sama dengan negara tujuan untuk penempatan pekerja formal dan menyesuaikan kembali persyaratan penempatan PMI.
\end{abstract}

Kata kunci: migrasi berulang, Pekerja Migran Indonesia, regresi logistik biner, stratified systematic sampling, SDGS 8

\section{ABSTRACT}

International labor migration grows rapidly following demographic transformation, giving rise to new pattern of movement: repeated migration. As a labor-sending country, Indonesia is facing complex problems associated with the protection and social impacts of repeated migration. Taking a case study of former migrant workers in Purworejo Village, Kendal Regency, this research aims to find out the general picture, the determinants, and the tendency to repeat their migration seen through the perspective of economic, human capital, demographic, and social capital characteristics. This study uses primary data source with systematic stratified sampling method. Through descriptive analysis, it is known that the majority of former migrant workers repeated their migrations. Through binary logistic regression analysis, five variables: employment, education, entrepreneurship training, age at first migration, and marital status were shown to significantly influence repeat migration. Former migrants that in their first migration worked for the informal sector, only educated in junior high school or below, had never received entrepreneurial training, young, and single have the bigger odds to repeat their migration. While work experience, language skill, number of household members, participation of the migrant community, and the existance of family migrant are not significantly effect repeat migration decision. The government is expected to intensify cooperation with destination countries for the placement of formal workers and readjust the registration requirements for migrant workers.

Keywords: repeated migration, migrant workers, binary logistic regression, stratified systematic sampling, SDGS 8 


\section{PENDAHULUAN}

Migrasi merupakan komponen utama dalam ilmu demografi yang berkaitan dengan dinamika kependudukan di samping fertilitas dan mortalitas. Migrasi dapat dibahas melalui berbagai konteks dalam bidang kehidupan, salah satunya pada lingkup ketenagakerjaan. Konsep migrasi tenaga kerja internasional dewasa ini semakin diminati seiring dengan pesatnya perkembangan teknologi transportasi dan komunikasi. Lebih lanjut, perkembangan sektor industri juga meningkatkan kebutuhan akan tenaga kerja asing. Terkait dengan situasi tersebut, ILO berfokus untuk meningkatkan kelayakan kerja bagi pekerja migran, yang lebih lanjut tertuang dalam tujuan kesepuluh Sustainable Development Goals (SDGs). Beberapa fakta tersebut sekaligus membuktikan bahwa migrasi tenaga kerja merupakan isu yang krusial.

Migrasi tenaga kerja internasional dapat terjadi dalam berbagai pola. Pola migrasi pekerja migran yang sering dijumpai adalah migrasi berulang. Mereka yang melakukan migrasi berulang melakukan perpindahan dengan frekuensi lebih dari satu kali. Dalam melakukan migrasi berulang, pekerja migran yang telah kembali dari migrasi pertamanya kemudian melakukan migrasi internasional selanjutnya. Migrasi berulang merupakan fenomena yang umum terjadi di kalangan pekerja migran, termasuk di Indonesia. Di kawasan Asia Tenggara, Indonesia merupakan salah satu negara dengan jumlah pekerja migran terbanyak setelah Filipina (World Bank, 2017). Pemerintah Indonesia memfasilitasi migrasi tenaga kerja internasional melalui program penempatan Pekerja Migran Indonesia (PMI) yang sebelumnya dikenal sebagai Tenaga Kerja Indonesia (TKI). Tingginya minat masyarakat untuk menjadi PMI dicerminkan kecenderungan meningkat pada total penempatan PMI (Tabel 1).

Tabel 35. Lima negara dengan jumlah penempatan PMI terbanyak tahun 2014-2018.

\begin{tabular}{lrcccr}
\hline \multirow{2}{*}{ Negara Tujuan } & \multicolumn{5}{c}{ Jumlah Penempatan PMI } \\
\cline { 2 - 6 }$(1)$ & \multicolumn{1}{c}{$(2014$} & 2015 & 2016 & 2017 & \multicolumn{1}{c}{2018} \\
\hline Malaysia & 127.870 & 97.748 & 87.623 & 88.991 & 90.671 \\
\hline Taiwan & 82.665 & 75.304 & 77.087 & 62.823 & 72.373 \\
\hline Hong Kong & 35.050 & 15.322 & 14.434 & 69.182 & 73.917 \\
\hline Singapura & 31.680 & 20.895 & 17.700 & 13.379 & 18.324 \\
\hline Arab Saudi & 44.325 & 23.000 & 13.538 & 6.471 & 5.894 \\
\hline Lainnya & 108.284 & 43.468 & 24.069 & 22.053 & 22.461 \\
\hline Total & 429.874 & 275.737 & 234.451 & 262.899 & 283.640
\end{tabular}

Sumber: Pusat Penelitian, Pengembangan, dan Informasi BNP2TKI

Secara umum, peningkatan penempatan PMI terjadi pada tahun 2017 dan 2018 setelah sebelumnya mengalami penurunan cukup signifikan pada tahun 2015-2016 karena adanya moratorium untuk keberangkatan ke negara-negara di Timur Tengah. Kebijakan moratorium tersebut berpengaruh terhadap perubahan negara tujuan yang saat ini lebih didominasi oleh negara-negara di Asia seperti Malaysia, Taiwan, dan Hong Kong. Tingginya minat masyarakat untuk menjadi PMI disertai oleh problematika yang kompleks. Setiap tahunnya, Badan Nasional Penempatan dan Perlindungan TKI (BNP2TKI) atau yang kini beralih nama menjadi Badan Penempatan dan Pelidungan PMI (BP2MI) merilis data pengaduan PMI bermasalah. Pada tahun 2018, jumlah pengaduan mengalami peningkatan menjadi 4.696 kasus (BNP2TKI, 2019). Tingginya angka tersebut mencerminkan masih banyak hak-hak PMI yang belum terpenuhi secara utuh oleh majikan maupun agensi. Sepanjang tahun 2018, kasus terbanyak yang dicatatkan oleh BNP2TKI adalah PMI tidak berdokumen atau ilegal. Penempatan PMI yang tidak sesuai prosedur tersebut sering kali berujung pada deportasi atau pemulangan paksa.

Problematika berikutnya adalah tingginya dominasi penempatan PMI yang berketerampilan rendah (low skilled). Dari segi pendidikannya, nyaris 70 persen PMI hanya menamatkan SMP ke bawah. Mayoritas PMI bekerja pada sektor pekerjaan yang tidak membutuhkan keterampilan tinggi seperti pekerja domestik, pengasuh, operator pabrik, pekerja perkebunan, dan pekerja pabrik. Penempatan PMI berketerampilan rendah inilah yang membuat PMI rentan mengalami 
tindakan eksploitasi dari majikan. Beberapa tindakan eksploitasi tersebut diantaranya jam kerja yang tidak manusiawi, gaji tidak dibayar, jenis pekerjaan yang tidak sesuai perjanjian, serta terjadinya perdagangan manusia (human-trafficking).

Dampak yang ditimbulkan oleh migrasi berulang lebih menitikberatkan pada problematika sosial, utamanya terhadap keluarga yang ditinggalkan. Penggantian peran orang tua dalam tumbuh kembang anak sering kali dilakukan oleh PMI di Indonesia. Penelitian Barbee (2017) menunjukkan bahwa migrasi orang tua berasosiasi pada rendahnya kecenderungan anak untuk bersekolah dan rendahnya rata-rata skor ujian mereka. Tidak berhenti sampai di sana, migrasi berulang juga rawan menimbulkan perceraian. Data BNP2TKI (2019) menunjukkan bahwa 1 dari 4 PMI yang ditempatkan pada tahun 2018 berstatus cerai. Maraknya perceraian di kalangan PMI dibuktikan dengan dominannya PMI pada kasus perceraian di Kabupaten Malang (Mazda, 2019) dan Kabupaten Blitar (Hasani, 2019).

Perulangan migrasi tenaga kerja internasional dapat dilihat dari berbagai perspektif, diantaranya dari segi ekonomi, modal manusia, demografi, sosial, hingga kebijakan setiap negara. Masing-masing dimensi tersebut memiliki problematika yang juga menunggu untuk dipecahkan. Keterbatasan ekonomi merupakan faktor paling umum yang melatarbelakangi migrasi berulang PMI. Meskipun berekspektasi mendapatkan gaji yang lebih tinggi di negara tujuan, banyak pula dijumpai kasus gaji tidak dibayar seperti kasus di Malaysia (Aud, 2018). Lebih lanjut, mayoritas PMI juga masih menggunakan remitansi sebatas untuk kebutuhan konsumtif saja. Dari segi kemampuan atau modal manusia, rendahnya pendidikan formal mayoritas PMI membuat minimnya wawasan sehingga rentan dieksploitasi dan ditipu, seperti kasus overcharged yang banyak dialami PMI di Hong Kong dan Taiwan (Mappapa, 2017; Nugroho, 2017). Dari perspektif karakteristik demografisnya, migrasi PMI yang didominasi oleh perempuan sayangnya juga disertai dengan maraknya kasus pelecehan seksual dan kekerasan. Lebih lanjut, masalah maladministrasi (pemalsuan dokumen) terkait dengan batas usia juga masih sering dijumpai, membuat daftar kasus perdagangan manusia dan pekerja anak semakin panjang. Dari segi sosial, migrasi bahkan telah menjadi budaya di beberapa daerah kantung PMI. Problematika yang mengemuka adalah bahwa sering kali penempatan PMI ilegal/nonprosedural justru didorong oleh pihak keluarga.

Studi kasus dilakukan untuk menjawab tujuan penelitian ini. Dari seluruh provinsi, Jawa Tengah menempati urutan kedua wilayah dengan jumlah penempatan PMI terbanyak tahun 2018. Di Jawa Tengah terdapat beberapa daerah basis rekrut PMI (kantung TKI), salah satunya adalah Kabupaten Kendal dengan jumlah penempatan tertinggi kedua (7.812 orang) pada tahun 2018. Dalam lingkup Kabupaten Kendal, Desa Purworejo merupakan salah satu desa dengan penempatan PMI terbanyak (Rochaniyah \& Indrayati, 2019). Tingginya mobilitas PMI asal Desa Purworejo membuatnya ditetapkan sebagai percontohan program Desa Migran Produktif (Desmigratif) oleh Kementerian Ketenagakerjaan pada tahun 2017. Karakteristik yang menarik dari migran asal Desa Purworejo adalah bahwa sebagaian besar melakukan migrasi berulang sehingga cocok untuk dijadikan populasi dalam penelitian ini.

Penelitian-penelitian tentang migrasi berulang belum banyak dilakukan di Indonesia. Literatur migrasi berulang dalam lingkup internasional juga masih terbatas. Noveria (2017) melakukan penelitian kualitatif yang mengupas secara mendalam faktor-faktor penyebab mantan TKI di Desa Sukorejo Wetan, Kabupaten Tulungagung melakukan migrasi berulang. Temuan menarik dari penelitian ini adalah bahwa sebagian besar remitansi digunakan untuk kebutuhan konsumtif, hanya sedikit yang dikembangkan menjadi usaha produktif. Lebih lanjut, melalui focus group discussion, wawancara mendalam, dan observasi, didapatkan bahwa faktor-faktor yang memengaruhi migrasi berulang diantaranya keterbatasan remitansi, kesulitan beradaptasi dengan kondisi daerah asal, keterbatasan kemampuan berwirausaha, dan keberadaan jaringan sosial.

Selain Noveria (2017), terdapat beberapa penelitian terkait migrasi berulang diantaranya Tresilo (2015), Zulfaqar (2013), dan Qoriani (2017). Namun, ketiga penelitian yang disebutkan terakhir tidak secara spesifik mengukur determinan terjadinya migrasi berulang, melainkan determinan minat migrasi berulang. Melalui pemodelan regresi logistik, Tresilo, Sumarsono, dan Qosjim (2015) menyimpulkan bahwa pendapatan dan status pekerjaan berpengaruh signifikan terhadap minat mantan TKI di Kabupaten Jember untuk bermigrasi kembali. Sedangkan menurut Qoriani (2017), variabel usia, status pekerjaan, remitansi, lama pendidikan, dan jenis penyalur 
memengaruhi minat migrasi berulang mantan pekerja migran perempuan di Desa Cihaur, Kabupaten Cianjur. Zulfaqar (2013) mengambil perspektif yang berbeda dengan meneliti mantan TKI yang membuka usaha di Provinsi Jawa Barat. Hasil yang didapatkan adalah variabel pendapatan, keuntungan, lama bekerja di negara sebelumnya, investasi, dan negara penempatan secara signifikan memengaruhi keinginan untuk kembali bermigrasi. Berdasarkan penelitianpenelitian di atas, dapat disimpulkan bahwa di Indonesia masih diperlukan penelitian tentang migrasi berulang PMI, utamanya dengan pendekatan empiris dan mengukur realitas (tidak sekadar minat). Penelitian ini diharapkan dapat turut mengisi research gap tersebut.

Setiap migrasi membawa dampak yang besar bagi pelakunya. Sayangnya, konsekuensi yang harus ditanggung sering kali tidak seimbang dengan hasil yang didapatkan. Problematika tersebut menjadi urgensi untuk segera diselesaikan. Berangkat dari permasalahan yang diuraikan di atas, penelitian ini memiliki tiga tujuan. Pertama, untuk mengetahui gambaran umum karakteristik mantan PMI. Kedua, menganalisis variabel-variabel yang memengaruhi migrasi berulang mantan PMI. Kemudian, secara lebih mendalam penelitian ini juga bertujuan menganalisis kecenderungan migrasi berulang mantan PMI dalam lokus penelitian yang sama. Dalam menjawab ketiga tujuan penelitian tersebut, penelitian ini mengambil studi kasus di Desa Purworejo, Kabupaten Kendal.

\section{METODE}

Secara teoretis, migrasi didefinisikan sebagai perubahan tempat tinggal baik secara permanen maupun semipermanen, tanpa ada batasan jarak, secara sukarela maupun tidak, dan dalam lingkup internal maupun internasional (Lee, 1966). Arus migrasi pada era modern semakin deras, melewati batas-batas ruang, dan terjadi pada berbagai kondisi. Konsep migrasi konvensional mengalami perkembangan menjadi pola-pola yang lebih kompleks, salah satunya adalah migrasi berulang. Constant dan Zimmerman (2011) menjelaskan bahwa pada era globalisasi pasar tenaga kerja, migran tidak lagi membuat keputusan migrasi permanen, lebih sering dijumpai mereka yang kembali, pindah, atau menjadi migran berulang atau sirkuler. Migrasi sirkuler atau berulang adalah pergerakan sistematis dan reguler migran dari negara asal ke negara tujuan, utamanya untuk mencari pekerjaan.

Berkembangnya pola migrasi berulang internasional tidak selaras dengan minimnya literatur dan teori untuk mendalaminya. Massey et al. (1993) bahkan menyebutkan bahwa belum ada teori yang menyeluruh dan koheren perihal migrasi internasional, yang tersedia hanya sekumpulan fragmen teori yang terpisah-pisah. Meskipun demikian, terdapat beberapa leading theory migrasi yang digunakan dalam penelitian ini, diantaranya: teori ekonomi neoklasik (human capita), dual labor market theory, dan social capital-network theory. Modal manusia (human capital) merupakan aspek yang tidak dapat dipisahkan dari teori ekonomi neoklasik. Teori ekonomi neoklasik menempatkan human capital sebagai aspek yang berpengaruh signifikan terhadap probabilita terjadinya migrasi internasional. Sebelum melakukan migrasi, seseorang akan menginvestasikan sumber dayanya untuk mendapatkan modal diri seperti pendidikan, keterampilan bekerja, dan keterampilan berbahasa. Lebih lanjut, mereka akan melakukan migrasi ke negara yang dapat mengoptimalkan produktivitas dengan kemampuan yang mereka miliki (Massey et al., 1993; Massey dan Espinosa; 1997).

Teori social capital-network theory mengemukakan bahwa jaringan migran merupakan salah satu pembentuk modal sosial (social capita), yaitu nilai atau sumber daya yang tumbuh pada individu atau kelompok dengan membentuk hubungan sosial yang baik dan tahan lama (Loury, 1977; Coleman, 1990; Buordieu dan Wacquant, 1992 dalam Massey \& Espinosa, 1997). Keberadaan jaringan migran meningkatkan kemungkinan terjadinya migrasi internasional, utamanya karena dapat meminimalisasi biaya dan risiko sehingga proses migrasi menjadi lebih menguntungkan. Sedangkan teori dual labor market menggarisbawahi bahwa terjadinya inflasi struktural, problem motivasional, dualisme ekonomi, dan karakteristik dari penawaran tenaga kerja memicu terjadinya migrasi internasional. Pekerja migran yang dibutuhkan di negara industri modern secara umum harus memenuhi kriteria tertentu, diantaranya mampu bekerja dengan gaji rendah, kondisi yang tidak stabil, dan tantangan berkaitan dengan dunia modern. Massey et al. (1993) menyebutkan bahwa kriteria tersebut secara umum dapat dipenuhi oleh individu dengan karakteristik demografis tertentu, diantaranya perempuan dan mereka yang berusia muda. 
Berdasarkan teori-teori tersebut, Massey \& Espinosa (1997) menguraikan bahwa dari segi mikro atau pada level individu terdapat beberapa dimensi determinan migrasi berulang internasional yaitu dimensi ekonomi, modal manusia (human capital), demografi, dan modal sosial (social capital). Dimensi-dimensi tersebut yang kemudian menyusun kerangka pikir dari penelitian ini (Gambar 1).

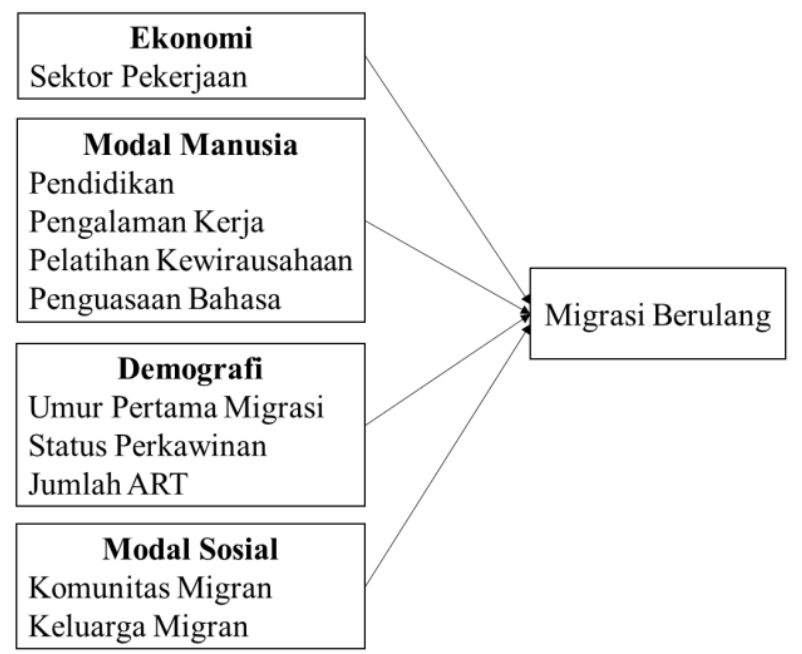

Gambar 1. Kerangka pikir penelitian

Dimensi ekonomi diturunkan dari teori ekonomi neoklasik dan dual system theory, diukur dengan variabel status pekerjaan pada migrasi pertamanya. Dimensi modal manusia merupakan salah satu yang penting menurut teori ekonomi neoklasik, diukur melalui variabel pendidikan, pengalaman kerja, keikutsrtaan pada pelatihan kewirausahaan, dan penguasaan bahasa pada migrasi pertama. Lebih lanjut, dimensi demografi mencerminkan karakteristik individu pada saat pertama kali bermigrasi, mencakup umur pertama, status perkawinan, dan jumlah anggota rumah tangganya. Di samping ketiga dimensi tersebut, dimensi modal sosial juga mengambil peran penting dalam migrasi internasional menurut network theory. Dimensi modal sosial diukur melalui variabel keikutsertaan dalam komunitas migran dan keberadaan keluarga yang pernah bermigrasi. Pada Gambar 1, "Migrasi Berulang" di sisi kanan kerangka pikir menunjukkan status migrasi seseorang: migrasi berulang atau migrasi tidak berulang. Sedangkan anak panah dari setiap dimensi menuju migrasi berulang menunjukkan adanya pengaruh setiap variabel dalam dimensidimensi tersebut terhadap migrasi berulang. Kerangka pikir tersebut lebih lanjut akan menjadi dasar penelitian ini dalam menguji determinan migrasi berulang secara empiris.

Penelitian ini berfokus untuk menganalisis determinan migrasi berulang mantan Pekerja Migran Indonesia (PMI) di Desa Purworejo, Kabupaten Kendal. Variabel dependen yang digunakan adalah status migrasi berulang, terdiri atas kategori migrasi berulang dan migrasi tidak berulang. Variabel dependen tersebut kemudian dianalisis bersama sepuluh variabel independen yang digambarkan dalam kerangka pikir (Gambar 1). Selain kesepuluh variabel independen tersebut, terdapat beberapa variabel lain yang sebatas dianalisis secara deskriptif untuk melengkapi hasil penelitian. Karakteristik mantan PMI yang ditangkap dalam penelitian ini ditentukan untuk migrasi pertama karena secara teoretis karakteristik migrasi pertama merupakan penentu bagi terjadinya migrasi-migrasi setelahnya. Penelitian ini mengambil studi kasus di Desa Purworejo, Kabupaten Kendal, Provinsi Jawa Tengah pada tanggal 24 s.d. 29 Desember 2019 yang diawali dengan kegiatan pembentukan kerangka sampel pada tanggal 18 s.d. 20 Desember 2019. Penelitian ini hanya mencakup penduduk Desa Purworejo dalam periode tersebut yang pernah bekerja di luar negeri seumur hidupnya atau selanjutnya disebut sebagai mantan PMI. Penelitian ini menggunakan sumber data primer yang diperoleh melalui kegiatan survei dengan moda pengumpulan data wawancara tatap muka dan menggunakan instrumen kuesioner. Sedangkan kerangka sampel terlebih dahulu dibentuk dengan sistem pendataan pintu ke pintu.

Populasi target dalam penelitian ini adalah penduduk Desa Purworejo yang berstatus mantan PMI. Kerangka sampel yang digunakan adalah Daftar Mantan Pekerja Migran Indonesia di Desa 
Purworejo, Kabupaten Kendal. Populasi target yang tercakup dalam kerangka sampel ini berjumlah 252 orang. Sampel diambil menggunakan metode sampling stratified systematic. Terdapat dua strata yang terbentuk: strata mantan migran berulang dan strata mantan migran tidak berulang. Kemudian, setiap strata diambil sampel secara sistematis, menghasilkan sejumlah 161 orang sampel terpilih. Dari hasil pencacahan di lapangan, sebanyak 154 orang berhasil diwawancarai. Jumlah sampel tersebut yang kemudian digunakan dalam analisis inferensia.

Dalam rangka menjawab tujuan penelitian, dilakukan analisis deskriptif dan analisis inferensia. Analisis deskriptif ditujukan untuk menjawab tujuan penelitian pertama, sedangkan analisis inferensia digunakan untuk menjawab tujuan penelitian kedua dan ketiga. Analisis deskriptif dilakukan untuk mempermudah penyampaian hasil penelitian secara umum dengan menyajikan ukutan rata-rata, proporsi, dan total yang diestimasi dari data sampel. Lebih lanjut, disajikan pula tabel tabulasi silang antara variabel independen kategorik dengan status migrasi. Analisis inferensia dilakukan dengan memodelkan status migrasi terhadap kesepuluh variabel independen menggunakan metode analisis regresi logistik biner. Model regresi logistik biner disusun sebagai berikut:

$\ln \left(\frac{\pi}{1-\pi}\right)=\alpha+\beta_{1}$ Sektor Pekerjaan $+\beta_{2}$ Pendidikan $[$ SD ke bawah $]+\beta_{3}$ Pendidikan $[$ SMP $]+$

$\beta_{4}$ Pengalaman Kerja $+\beta_{5}$ Pelatihan Kewirausahaan $+\beta_{6}$ Penguasaan Bahasa + $\beta_{7}$ Usia Pertama Migrasi $+\beta_{8}$ Status Perkawinan $+\beta_{9}$ Jumlah ART + $\beta_{10}$ Komunitas Migran $+\beta_{11}$ Keluarga Migran.

dimana:

$\pi=$ probabilita untuk migrasi berulang $(\mathrm{Y}=1)$

$\alpha=$ koefisien intersep

$\beta_{1} \ldots \beta_{11}=$ koefisien regresi/slope

Setelah pembentukan model, dilakukan evaluasi model menggunakan pengujian goodness of fit (uji Hosmer-Lemeshow), tabel klasifikasi, dan kurva receiver operating characteristic (ROC). Uji Hosmer-Lemeshow menguji hipotesis nol model fit, model dinyatakan fit ketika nilai statistik uji kurang dari $\chi_{0,05 ; 8}^{2}=15,507$. Sedangkan tabel klasifikasi dan kurva ROC digunakan untuk melihat performa model dalam mengelompokkan observasi. Setelah melakukan evaluasi model, dilakukan pengujian signifikansi parameter secara simultan menggunakan uji likelihood ratio. Ketika pengujian simultan signifikan, dilakukan pengujian secara parsial menggunakan uji Wald. Selanjutnya, interpretasi hasil pemodelan dilakukan dengan ukuran odds ratio yang menggambarkan kecenderungan mantan PMI dengan tertentu untuk melakukan migrasi berulang.

\section{HASIL DAN PEMBAHASAN}

Desa Purworejo merupakan salah satu desa basis PMI di Kabupaten Kendal. Rekam jejak migrasi penduduknya sudah dimulai sejak akhir 1980-an. Seiring berjalannya waktu, migrasi semakin menjadi hal yang biasa dilakukan masyarakat Desa Purworejo. Migrasi PMI dari Desa Purworejo mendapatkan perhatian dengan ditetapkannya desa ini sebagai salah satu desa migran produktif (desmigratif). Kegiatan survei yang dilakukan oleh peneliti di Desa Purworejo menghasilkan beberapa temuan menarik.

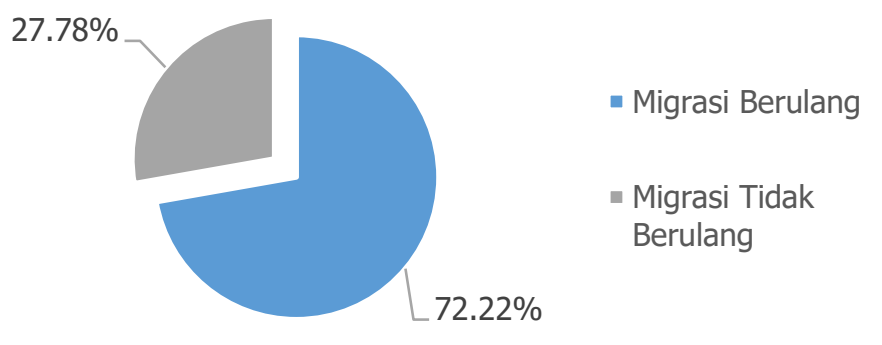

Sumber: data primer, diolah.

Gambar 2. Persentase mantan PMI di Desa Purworejo, Kabupaten Kendal menurut status migrasinya. 
Dari seluruh mantan PMI di Desa Purworejo, mayoritas melakukan migrasi berulang dengan dominasi yang cukup besar, mencapai 72,22 persen (Gambar 2). Lebih jauh, jika dilihat dari frekensinya, mayoritas melakukan migrasi berulang sebanyak dua kali (31,13 persen) dengan durasi rata-rata 75 bulan atau 6,25 tahun. Hal ini menunjukkan bahwa migrasi berulang merupakan fenomena yang cukup umum dilakukan oleh kalangan migran di Desa Purworejo, Kabupaten Kendal.

Karakteristik mantan PMI di Desa Purworejo juga bervariasi jika dibedakan menurut status migrasinya. Terdapat indikasi kecenderungan pada mantan PMI dengan karakteristik tertentu untuk melakukan migrasi berulang. Indikasi kuat untuk migrasi berulang ditunjukkan oleh kelompok mantan PMI yang pada saat migrasi pertamanya bekerja pada sektor informal. Fenomena ini dapat terjadi karena secara ekonomi, mantan PMI di sektor informal berpenghasilan lebih rendah daripada sektor formal sehingga migrasi satu kali sering kali dianggap belum cukup untuk mencapai tujuan migrasi. Lebih jauh, terdapat kebijakan dari pemerintah Indonesia bahwa penempatan PMI di sektor formal lebih diutamakan bagi mereka yang belum pernah bermigrasi. Mantan PMI yang pada saat migrasi pertamanya berpendidikan SMP dan SD ke bawah juga menunjukkan indikasi kecenderungan yang kuat untuk melakukan migrasi berulang. Tidak hanya pendidikan formal, mereka yang tidak pernah mendapatkan pelatihan kewirausahaan juga menunjukkan indikasi untuk bermigrasi lebih dari satu kali. Indikasi-indikasi yang didapatkan melalui analisis tabulasi silang tersebut masih memerlukan pengujian secara inferensia melalui pemodelan regresi logistik biner.

Berdasarkan kerangka pikir yang sudah diuraikan pada bagian sebelumnya, analisis inferensia dilakukan dengan memodelkan status migrasi seseorang dengan sepuluh variabel independen yang berasal dari dimensi ekonomi, modal manusia, demografi, dan modal sosial. Pada pemodelan regresi logistik biner, status migrasi terdiri atas dua kategori yaitu migrasi berulang [1] dan migrasi tidak berulang [0], kode [0] sebagai kategori referensi. Pengujian signifikansi parameter dalam penelitian ini menggunakan taraf signifikansi 5 persen. Hasil analisis regresi logistik biner disajikan dalam Tabel 4.

Sebelum menginterpretasikan model yang terbentuk, terlebih dahulu dilakukan evaluasi model menggunakan pengujian Hosmer-Lemeshow, tabel klasifikasi, dan kurva ROC. Hasil dari pengujian Hosmer-Lemeshow menunjukkan bahwa dengan taraf signifikansi 5 persen, model dapat dinyatakan fit (Tabel 2). Sedangkan tabel klasifikasi model menunjukkan persentase observasi yang dapat diprediksi secara benar oleh model sebesar 83,8 persen. Dengan nilai akurasi tersebut, model telah cukup akurat dalam memprediksi kelas observasi. Selanjutnya, kurva ROC dari model regresi logistik biner yang telah terbentuk di atas memiliki luasan area di bawah kurva sebesar 0,883 . Luasan tersebut termasuk dalam kategori "diskriminasi baik". Hasil evaluasi model tersebut menjadi indikator bahwa model telah dapat digunakan untuk analisis selanjutnya.

Tabel 2. Ringkasan hasil uji Hosmer-Lemeshow.

\begin{tabular}{ccc}
\hline Statistik Uji $\left(G_{H L}^{2}\right)$ & Derajat Bebas (df) & $P$-value \\
\hline$(1)$ & $(2)$ & $(3)$ \\
\hline 6,467 & 8 & 0,595 \\
\hline Sumber: data primer, diolah. &
\end{tabular}

Dari sepuluh variabel independen yang diregresikan, penelitian ini juga menganalisis apakah keseluruhan variabel tersebut secara bersama-sama memengaruhi migrasi berulang mantan PMI di Desa Purworejo. Pengujian simultan ini dilakukan menggunakan uji likelihood ratio (LR). Berdasarkan hasil pada Tabel 3, dapat disimpulkan bahwa dengan tingkat signifikansi 5 persen, seluruh variabel independen secara bersama-sama memengaruhi migrasi berulang mantan PMI di Desa Purworejo. Dengan kata lain, terdapat minimum satu variabel independen dengan $\beta \neq 0$. Selanjutnya, untuk mengetahui variabel mana yang memiliki $\beta \neq 0$ dilakukan pengujian signifikansi parameter secara parsial.

Tabel 3. Ringkasan hasil uji likelihood ratio.

\begin{tabular}{ccc}
\hline Statistik Uji $\left(G^{2}\right)$ & Derajat Bebas (df) & $P$-value \\
\hline$(1)$ & $(2)$ & $(3)$ \\
\hline 59,939 & 11 & 0,000 \\
\hline
\end{tabular}


Sumber: data primer, diolah

Pengujian signifikansi parameter secara parsial dilakukan menggunakan uji Wald. Uji Wald menguji hipotesis alternatif dua arah sehingga hipotesis nol $(\beta=0)$ akan ditolak ketika statistik Wald melebihi $\chi_{0,05 ; 1}^{2}=3,841$ atau $p$-value $<0,05$. Hasil pengujian pada Tabel 4 menunjukkan bahwa terdapat lima dari sepuluh variabel yang memenuhi syarat ini. Dengan demikian, menggunakan tingkat signifikansi 5 persen, dapat disimpulkan bahwa variabel sektor pekerjaan, pendidikan, pelatihan kewirausahaan, usia pertama migrasi, dan status perkawinan terbukti secara signifikan memengaruhi migrasi berulang mantan PMI di Desa Purworejo. Sedangkan dengan tingkat signifikansi yang sama, belum terdapat cukup bukti untuk menyatakan bahwa pengalaman kerja, penguasaan bahasa, jumlah ART, komunitas migran, dan keluarga migran berpengaruh signifikan. Sejalan dengan tujuan ketiga dari penelitian ini, persamaan regresi logistik biner juga akan digunakan untuk menganalisis kecenderungan dari variabel-variabel tersebut terhadap status migrasi berulang dan tidak berulang. Analisis kecenderungan dilakukan menggunakan ukuran odds ratio yang diperoleh dari mengeksponensialkan nilai koefisien regresi logistik biner. Hasil perhitungan odds ratio disajikan dalam Tabel 4.

Tabel 4. Ringkasan hasil estimasi parameter, uji Wald, dan odds ratio

\begin{tabular}{lccccc}
\hline \multicolumn{1}{c}{ Variabel } & $\hat{\beta}$ & $s e(\hat{\beta})$ & Wald & $p$-value & Odds Ratio \\
\hline Intersep & $(2)$ & $(3)$ & $(4)$ & $(5)$ & $(4)$ \\
\hline Sektor Pekerjaan & 0,407 & 2,010 & 0,041 & 0,840 & 1,502 \\
\hline Pendidikan [SD ke bawah] & 2,460 & 0,844 & 8,497 & $0,004^{*}$ & 11,707 \\
\hline Pendidikan [SMP] & 2,470 & 0,817 & 9,140 & $0,003^{*}$ & 11,828 \\
\hline Pengalaman Kerja & 1,804 & 0,719 & 6,291 & $0,012^{*}$ & 6,072 \\
\hline Pelatihan Kewirausahaan & 0,733 & 0,576 & 1,620 & 0,203 & 2,081 \\
\hline Penguasaan Bahasa & $-1,877$ & 0,682 & 7,568 & $0,006^{*}$ & 0,153 \\
\hline Umur Pertama Migrasi & 0,986 & 0,659 & 2,241 & 0,134 & 2,681 \\
\hline Status Perkawinan & $-0,141$ & 0,055 & 6,708 & $0,010^{*}$ & 0,868 \\
\hline Jumlah ART & 1,868 & 0,792 & 5,564 & $0,018^{*}$ & 6,474 \\
\hline Komunitas Migran & $-0,298$ & 0,168 & 3,155 & 0,076 & 0,742 \\
\hline Keluarga Migran & 0,005 & 0,526 & 0,000 & 0,992 & 1,005 \\
\hline Sumber: data & 0,118 & 0,527 & 0,050 & 0,823 & 1,125 \\
\hline
\end{tabular}

Sumber: data primer, diolah.

Keterangan:

*= signifikan pada tingkat signifikansi 0,05

Kategori referensi: sektor pekerjaan formal, pendidikan SMA ke atas, tidak memiliki pengalaman kerja, tidak pernah mengikuti pelatihan kewirausahaan, tidak menguasai bahasa, pernah kawin, tidak ikut komunitas migran, dan tidak ada keluarga migran.

Hasil regresi logistik biner menunjukkan bahwa mantan PMI yang bekerja pada sektor informal pada migrasi pertamanya memiliki kecenderungan 11,707 kali lebih besar untuk melakukan migrasi berulang. Secara lebih sepesifik, nilai odds ratio yang besar menunjukkan adanya kecenderungan dan asosiasi yang kuat bahwa mantan PMI yang pada migrasi pertamanya bekerja pada sektor informal akan bermigrasi berulang, sedangkan mereka yang bekerja pada sektor formal cenderung bermigrasi hanya satu kali. Hal yang perlu diperhatikan adalah bahwa sektor informal mencakup mereka yang diberi pekerjaan oleh pengguna perseorangan dan biasanya bekerja dengan sistem kontrak. Lebih lanjut, sektor informal lebih banyak berasosiasi dengan pekerjaan rumah tangga, tidak membutuhkan keterampilan tinggi, dan upah yang cenderung lebih rendah daripada sektor formal. Dengan durasi kerja yang dibatasi sistem kontrak, upah atau remitansi yang rendah sering kali belum dapat memenuhi ekspektasi kebutuhan migran sehingga migrasi berulang tidak terhindarkan.

Meningkatnya pendidikan yang ditamatkan akan diikuti dengan menurunnya kecenderungan bagi mantan pekerja migran di Desa Purworejo untuk melakukan migrasi berulang. Mantan PMI yang berpendidikan SD atau tidak lulus SD terbukti memiliki kecenderungan yang paling besar untuk migrasi berulang, mencapai 11,83 kali lebih besar dibandingkan mereka yang lulus SMA. Ketika pendidikan meningkat menjadi SMP, kecenderungan tersebut menurun secara 
signifikan meskipun angkanya masih besar. Dibandingkan dengan yang lulus SMA, mantan PMI yang hanya lulus SMP memiliki kecenderungan 6 kali lebih besar untuk melakukan migrasi berulang. Dengan demikian, peningkatan pendidikan sangat memengaruhi pola migrasi mantan PMI di Desa Purworejo. Temuan ini sejalan dengan hasil penelitian Constant \& Zimmerman (2011) bahwa pekerja migran di Jerman yang berpendidikan tinggi lebih tidak berasosiasi terhadap migrasi berulang. Hasil serupa juga didapati oleh Qoriani (2017) bahwa mantan TKW di Desa Cihaur, Kabupaten Cianjur yang pendidikannya lebih lama cenderung tidak berminat untuk bermigrasi kembali.

Pendidikan merupakan aspek modal manusia yang penting. Peningkatan pendidikan akan memperluas pilihan seseorang untuk menentukan pekerjaan dan pola migrasinya. Hal ini juga berkaitan dengan kesempatan yang tersedia. Kesempatan untuk bekerja di luar negeri sejauh ini lebih terbuka bagi mereka yang berpendidikan rendah meskipun dalam beberapa tahun terakhir pemerintah menggalakkan pembukaan kesempatan bagi mereka yang berpendidikan tinggi. Setelah migrasi pertama dilakukan, mantan PMI dihadapkan pada dua pilihan: bekerja dengan menetap di dalam negeri atau kembali bermigrasi. Ketika pendidikan rendah dan mantan PMI tidak terserap oleh lapangan kerja di dalam negeri, maka keputusan untuk bermigrasi kembali sering kali menjadi pilihan.

Pelatihan kewirausahaan merupakan bagian dari modal manusia yang terbukti secara signifikan memengaruhi migrasi berulang mantan PMI di Desa Purworejo. Pelatihan kewirausahaan merupakan kegiatan pelatihan yang ditujukan untuk memberikan kemampuan bagi peserta untuk mengembangkan usaha di dalam negeri. Hasil estimasi pada Tabel 4 menunjukkan bahwa odds ratio yang diperoleh sebesar 0,153 . Angka tersebut menjelaskan bahwa dibandingkan dengan yang pernah mengikuti pelatihan kewirausahaan, mantan PMI yang tidak pernah mengikuti kegiatan pelatihan kewirausahaan memiliki kecenderungan 6,5 kali lebih besar untuk migrasi berulang. Hasil tersebut sekaligus mengindikasikan kegiatan pelatihan kewirausahaan bagi masyarakat Desa Purworejo cukup efektif dalam menurukan kecenderungan bagi mantan PMI untuk bermigrasi kembali.

Bekerja sebagai PMI di luar negeri diminati oleh kalangan dari berbagai umur. Pada awal penyelenggaraan program kerja di luar negeri, para calon pekerja bahkan sering kali memanipulasi umur mereka agar memenuhi persyaratan. Dalam penelitian ini, umur pertama migrasi yang dicakup adalah umur sebenarnya pada saat mereka melakukan migrasi sebagai PMI pertama kali. Hasil analisis regresi logistik biner menunjukkan bahwa setiap pertambahan umur pertama migrasi satu tahun menurunkan kecenderungan untuk bermigrasi berulang secara signifikan. Secara lebih spesifik, mereka yang umur migrasi pertamanya lebih muda satu tahun memiliki kecenderungan 1,15 kali lebih besar untuk migrasi berulang. Hal ini sesuai dengan teori Dual Labor Market bahwa migrasi berulang cenderung terjadi pada mereka yang berusia muda karena memiliki waktu yang relatif lebih lama dalam perjalanan kariernya (Massey et al, 1993). Pembuktian secara empiris oleh Massey \& Espinosa (1997) juga menunjukkan hasil yang serupa. Lebih lanjut, penelitian Qoriani (2017) di Desa Cihaur, Kabupaten Cianjur menyimpulkan bahwa mantan TKW yang lebih tua cenderung tidak lagi berminat untuk bermigrasi.

Status perkawinan saat pertama kali bermigrasi telah terbukti berpengaruh signifikan terhadap kecenderunagn migrasi berulang mantan PMI di Desa Purworejo. Mantan PMI yang belum menikah pada saat migrasi pertamanya melakukan migrasi berulang dengan kecenderungan nyaris 6,5 kali lebih besar daripada yang berstatus pernah menikah. Temuan ini dapat dijelaskan bahwa terdapat beban psikologis dengan menjadi pekerja migran karena harus berjarak dengan keluarga inti, yaitu pasangan dan anak. Lebih lanjut, seseorang yang berada dalam ikatan pernikahan akan lebih terbatas pergerakan migrasinya, utamanya karena tuntutan biologis dan sosial. Pembuktian empiris dari teori tersebut juga berkesimpulan bahwa mereka yang belum menikah cenderung melakukan migrasi berulang (Constant \& Zimmerman, 2011; Massey \& Espinosa; 1997).

\section{KESIMPULAN}

Penelitian ini berfokus dalam menentukan determinan migrasi berulang mantan Pekerja Migran Indonesia (PMI) dengan mengambil studi kasus di Desa Purworejo, Kabupaten Kendal. Dari 
populasi target sejumlah 252 orang, sampel sebanyak 154 mantan PMI berhasil diwawancarai. Dalam rangka menjawab tujuan penelitian, dilakukan analisis deskriptif dan inferensia yang menghasilkan beberapa kesimpulan. Pertama, sebanyak 72,22 persen mantan PMI di Desa Purworejo melakukan migrasi berulang, dengan frekuensi keberangkatan paling banyak dilakukan adalah dua kali. Rata-rata durasi kerja berada pada kisaran 6-7 tahun. Lebih lanjut, sebagian besar mantan PMI tidak berminat untuk kembali bermigrasi. Indikasi kuat untuk migrasi berulang ditunjukkan oleh kelompok mantan PMI yang pada saat migrasi pertamanya bekerja pada sektor informal, berpendidikan SD ke bawah atau SMP, dan tidak pernah mengikuti pelatihan kewirausahaan.

Kedua, dari persamaan regresi logistik biner, terdapat lima variabel yang pada taraf signifikansi 5 persen terbukti signifikan memengaruhi migrasi berulang mantan PMI di Desa Purworejo. Kelima variabel tersebut adalah sektor pekerjaan, pendidikan, pelatihan kewirausahaan, umur migrasi pertama, dan status perkawinan. Sedangkan untuk lima variabel lainnya tidak terbukti berpengaruh signifikan. Ketiga, kecenderungan mantan PMI untuk migrasi berulang lebih besar bagi mereka yang memiliki karakteristik berikut: bekerja pada sektor informal, berpendidikan SD ke bawah dan SMP, tidak pernah mengikuti pelatihan kewirausahaan, bermigrasi pertama pada usia muda, dan belum pernah kawin pada migrasi pertamanya. Setiap karakteristik tersebut dibandingkan dengan kategori referensinya.

\section{DAFTAR PUSTAKA}

Aud. (2018, Desember 27). Ratusan Ribu TKI Kesulitan Mendapatkan Gaji. Diambil kembali dari CNN Indonesia:https://www.cnnindonesia.com/ekonomi/20181227132720-92-356750/ratusan-ribu-tkikesulitan-mendapatkan-gaji

Berbee, P. (2017). A Matter of Gendered Investment: Impacts of International Migration on Child Education in Indonesia [Master Thesis]. Lund University.

BNP2TKI. (2019). Data Penempatan dan Perlindungan PMI Periode Tahun 2018. Jakarta: PUSLITFO BNP2TKI.

Constant, A. F., \& Zimmerman, K. F. (2011). Circular and Repeat Migration: Counts of Exits and Years Away from the Host Country. Popul Res Policy, 495-515.

Hasani, A. (2019, Mei 25). Divorce rate among migrant workers at record high. Diambil kembali dari The Jakarta Post: https://www.thejakartapost.com/news/2019/05/25/divorce-rate-among-migrant-workersrecord-high.html

Lee, E. S. (1966). A Theory of Migration. Demography, 47-57.

Mappapa, P. L. (2017, Juni 27). Organisasi TKI Taiwan Keluhkan Praktik Overcharging. Diambil kembali dari Detiknews: overcharging

Massey, D. S., \& Espinosa, K. E. (1997). What's Driving Mexico-U.S. Migration? A Theoretical, Empirical, and Policy Analysis. American Journal of Sociology, 939-999.

Massey, D. S., Arango, J., Hugo, G., Kouaouci, A., Pallegrino, A., \& Taylor, J. E. (1993). Theories of International Migration: A Review and Appraisal. Population and Development Review, Vol. 19, No. 3, 431-466.

Mazda, G. (2019, Februari 28). Ironi Perceraian di Kabupaten Malang yang Tembus 6.878 Kasus Pertahun. Diambil kembali dari Kumparan: https://kumparan.com/tugumalang/ironi-perceraian-di-kabupatenmalang-yang-tembus-6-878-kasus-pertahun-1551325467144577934/full

Noveria, M. (2017). Migrasi Berulang Tenaga Kerja Migran Internasional: Kasus Pekerja Migran Asal Desa Sukorejo Wetan, Kabupaten Tulungagung. Jurnal Kependudukan Indonesia, 25-38.

Nugroho, B. P. (2017, Mei 3). Konjen RI Hong Kong: Kami Blacklist Majikan TKI yang Tidak Baik. Retrieved from Detiknews: https://news. detik.com/wawancara/d-3490157/konjen-ri-hong-kong-kami-blacklistmajikan-tki-yang-tidak-baik

Qoriani, I. (2016). Faktor-Faktor yang Memengaruhi Kembalinya Tenaga Kerja Wanita (TKW) dan Pemanfaatan Remitansi (Desa Cihaur, Cianjur). Bogor: Institut Pertanian Bogor.

Rochaniyah, N., \& Indrayati, A. (2019). Faktor Penarik dan Pendorong Mobilitas Eks TKI Desa Purworejo Kecamatan Ringinarum Kabupaten Kendal. Edu Geography, 174-180. 
Tresilo, Y. B., Sumarsono, S., \& Qosjim, A. (2015). Analisis Faktor yang Mempengaruhi Minat Mantan TKI untuk Bekerja Kembali ke Luar Negeri di Kabupaten Jember. Jurnal ISEI, 59-72.

World Bank. (2017). Indonesia's Global Workers: Juggling Opportunities and Risks. Jakarta: The World Bank Office.

Zulfaqar, V. (2013). Faktor-faktor yang mempengaruhi probabilitas TKI purna menjadi TKI kembali: studi kasus di Provinsi Jawa Barat 2011. Depok: Universitas Indonesia. 